\title{
(2) OPEN ACCESS \\ Dual SAVE technique for mechanical thrombectomy rescue on MCA bifurcation clots
}

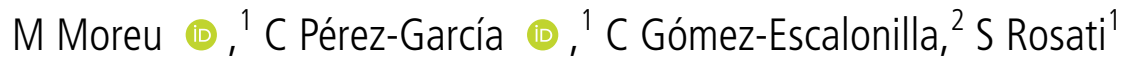

${ }^{1}$ Neurointerventional Unit, Radiology Department, Hospital Clínico Universitario San Carlos, Madrid, Spain ${ }^{2}$ Department of Neurology, Hospital Clínico Universitario San Carlos, Madrid, Spain

\section{Correspondence to} Dr M Moreu,

Neurointerventional Unit, Hospital Clínico Universitario San Carlos, Madrid 28040, Spain; manumoreu@gmail.com

Received 26 March 2020 Revised 5 May 2020 Accepted 9 May 2020 Published Online First 25 June 2020

\section{ABSTRACT}

The Stent retriever Assisted Vacuum-locked Extraction (SAVE) technique in mechanical thrombectomy consists of the simultaneous use of a stent retriever and a distal aspiration catheter, with the removal of both as a unit when performing the thrombectomy pass. This is a safe procedure that provides a high rate of first-pass reperfusion. ${ }^{1}$ In the distal M1 segment of the middle cerebral artery (MCA) occlusions, with the distal portion of the clot extending to the upper and lower MCA branches, mechanical thrombectomy can be challenging since the thrombus is not fully trapped, with risk of distal clot migration to the branch in which the retriever is not placed. In these cases the double stentretriever technique has been described as a rescue strategy. $^{2-4}$ We describe a case of the combined use of SAVE and double stent-retriever techniques as a rescue strategy in a patient with tandem occlusion of the proximal internal carotid artery and distal MCA-the D-SAVE technique. (video 1)

Correction notice This article has been corrected since it was published Online First. The acknowledgements section was added.

\section{Check for updates}

(C) Author(s) (or their employer(s)) 2020. Re-use permitted under CC BY-NC. No commercial re-use. See rights and permissions. Published by BMJ.

To cite: Moreu M, Pérez-

García C, Gómez-

Escalonilla C, et al.

$\checkmark$ Neurolntervent Surg 2020;12:1034.

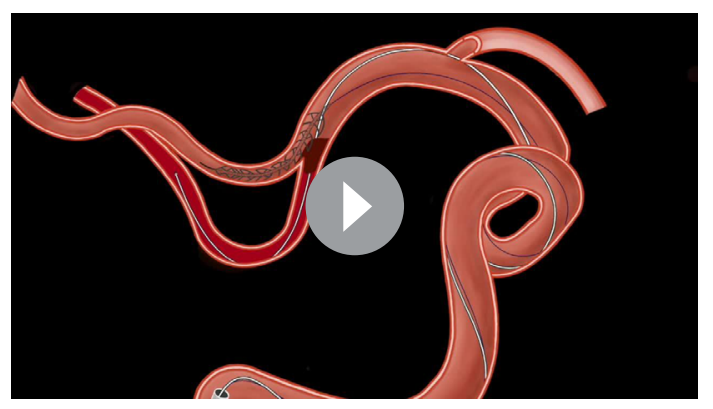

video 1.

\section{Twitter M Moreu @manumoreu}

Acknowledgements The open access fees for this technical video were sponsored by Stryker Iberica SL

Contributors Project development: MM, CP-G. Interventional procedure performance: MM,CP-G, SR. Data collection and management: MM, CG-E. Video writing/editing: MM. Drawings: CP-G. Revising the work critically for important intellectual content: MM, CP-G, SR, CG-E. Video final approval: MM, CP-G, SR, CG-E. Agreement to be accountable for all aspects of the work: MM, CP-G, SR, CG-E.

Funding The authors have not declared a specific grant for this research from any funding agency in the public, commercial or not-for-profit sectors.

Competing interests None declared.

Patient consent for publication Obtained.

Provenance and peer review Not commissioned; externally peer reviewed.

Open access This is an open access article distributed in accordance with the Creative Commons Attribution Non Commercial (CC BY-NC 4.0) license, which permits others to distribute, remix, adapt, build upon this work non-commercially, and license their derivative works on different terms, provided the original work is properly cited, appropriate credit is given, any changes made indicated, and the use is non-commercial. See: http:// creativecommons.org/licenses/by-nc/4.0/.

\section{ORCID iDs}

M Moreu http://orcid.org/0000-0002-9001-0661

C Pérez-García http://orcid.org/0000-0002-5450-148X

\section{REFERENCES}

1 Maus V, Behme D, Kabbasch C, et al. Maximizing first-pass complete reperfusion with save. Clin Neuroradiol 2018;28:327-38.

2 Asadi H, Brennan P, Martin A, et al. Double stent-retriever technique in endovascular treatment of middle cerebral artery saddle embolus. Stroke Cerebrovasc Dis . 2016;25:e9-11.

3 Klisch J, Sychra V, Strasilla C, et al. Double solitaire mechanical thrombectomy in acute stroke: effective rescue strategy for refractory artery occlusions? AJNR Am J Neuroradiol 2015;36:552-6.

4 Patro SN, lancu D. Dual-stent retrieval for mechanical thrombectomy of refractory clot in acute stroke as a rescue technique. CMAJ 2017;189:E634-7. 